\title{
Nodal segments and zygotic embryos in culture media for the in vitro propagation of tamarind
}

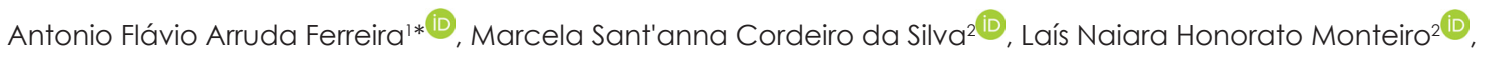

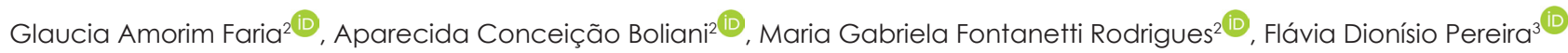 \\ Mato Grosso State University, Alta Floresta, Brazi \\ ${ }^{2}$ São Paulo State University, llha Solteira, Brazil \\ ${ }^{3}$ Federal Institute of Education, Science, and Technology, Morrinhos, Brazil \\ *Corresponding author, e-mail: arrudaferreira.af@gmail.com
}

\begin{abstract}
There has been a lack of research on the propagation methods of tamarind, hindering the availability and supply of its products. Considering the nutraceutical potential of tamarind and the long-time required to initiate production, this study aimed to evaluate the establishment of nodal segments and the germination of in vitro zygotic embryos of tamarind plants in culture media, salt concentrations, and activated charcoal, aiming at the establishment of an in vitro propagation protocol. For this purpose, MS and WPM media with 25, 50, 75 and $100 \%$ salt concentrations were used both with and without activated charcoal $\left(2 \mathrm{~g} \mathrm{~L}^{-1}\right)$ for the inoculation of nodal segments and zygotic embryos of tamarind. The experiment was conducted in a completely randomized experimental design, in a $2 \times 4 \times 2$ factorial scheme (culture media $\times$ salt concentrations $\times$ activated charcoal) with 20 replications. It was observed that the in vitro establishment of tamarind nodal segments is viable when using the MS medium with $75 \%$ of salts plus $2 \mathrm{~g} \mathrm{~L}^{-1}$ of activated charcoal and that for the germination of zygotic embryos there was no influence of the treatments. It was also observed that in order to increase the length of the formed plantlets, the MS and WPM media can be employed with $75 \%$ of salts.
\end{abstract}

Keywords: conservation, explants, plant tissue culture, micropropagation Tamarindus indica L.

\section{Introduction}

Native or little-explored fruits like tamarind (Tamarindus indica L.) have been currently evidenced for their exotic and striking flavor and due to the search by the consumer market for foods with bioactive compounds. This fruit species is especially important due to its nutritional and pharmacological properties, with a mesocarp rich in Vitamin $C$ and possessing antioxidant and anti-inflammatory activities (Maiti et al., 2018; Reis et al., 2016; Razali et al., 2015).

Considering these particularities, an obstacle for the establishment of commercial orchards and the extractivism of tamarind is its long juvenile period, in which the produced seedlings might take more than seven years to initiate the fructification stage (Ferreira et al., 2018). A viable option to obtain precocious plants for production has been the use of vegetatively produced seedlings, which, besides allowing the inheritance of genetic characteristics of agronomical interest, constitutes an expressive technique in fruit farming.

Among propagative methods, tissue culture has become an important tool in the production of quality seedlings to supply the need of the market for a more technified fruit farming, producing pathogen-free seedlings in a short period, in addition to the use for the creation and conservation of germplasm banks of species with agro-economical and nutraceutical importance (Gutiérrez et al., 2011). However, the shortage of reports in the literature regarding the factors involved in the production of seedlings of fruit species at a commercial level through this method limits the offer and the research (Brandstetter et al., 2016).

In this methodology, several factors might influence plant growth during the establishment, such as the environmental conditions, the culture medium, the concentration of salts and, most of all, the types of explants. During the in vitro establishment, the first and most important stage of this method is the selection of the most adequate vegetal material for future multiplication (Fermino Junior \& Scherwinski-Pereira, 2012).

Besides the characteristics related to the choice of the explant, another factor that interferes in the establishment and in vitro multiplication of plants is the culture medium, since it directly influences plant growth and development (Brandstetter et al., 2016). The composition and comparison of media are essential 
to establish in vitro production protocols for plantlets, verifying the interactions between mineral nutrients and the nutritional demands of each species (Lemes et al., 2016; Campos et al., 2013).

Within the context of the tamarind potential as an expanding fruit species, rich in nutraceutical substances, this work aimed to study the in vitro establishment of nodal segments and the germination of zygotic embryos of tamarind cultivated in culture media in concentrations of salts and activated charcoal, aiming to contribute as a propagation method for the conservation of the species and for in vitro studies.

\section{Material and Methods}

Vegetal material

The tamarind fruits (Tamarindus indica L.) were dispulped in a sieve ( $3 \mathrm{~mm}$ ) under running water for the removal of the seeds. Afterward, the reproductive material was shade dried at ambient temperature $\left( \pm 28^{\circ} \mathrm{C}\right)$ for 48 hours and then stored in kraft paper bags in a dry chamber $\left(15^{\circ} \mathrm{C}\right.$ and $45 \%$ UR) for 15 days. The experiments were performed in the Laboratory of Culture of Vegetal Tissues (LCTV) of the Federal Institute of Education, Science, and Technology of Goiano - Campus Rio Verde.

In vitro establishment of the nodal segments

The seeds were scarified with sandpaper number 80 in the hilum region, immersed in distilled water for 24 $h$, sowed in plastic boxes filled with autoclaved sand, and installed in a laboratory with control of temperature $\left(25.5 \pm 2.0^{\circ} \mathrm{C}\right)$ and relative humidity $(52.5 \pm 2.0 \%)$. Nodal segments with approximately $1 \mathrm{~cm}$ length, containing one bud, were collected 40 days after sowing.

The nodal segments were immersed for 1 minute in $70 \%$ (v:v) ethanol and $1 \%$ active chlorine (Qboa ${ }^{\circledR}$ ) for 30 min with three drops of a neutral detergent (Tween 20) (Dinâmica ${ }^{\circledR}$ ). The triple wash was performed in a laminar flow cabinet using distilled and autoclaved water. Afterward, the explants were vertically inoculated in test tubes $(20 \times 150 \mathrm{~mm})$ filled with $20 \mathrm{~mL}$ of the culture media, which were filled with transparent plastic wrap.

The treatments consisted of the use of an MS (Murashige \& Skoog, 1962) or WPM medium (Lloyd \& Mccown, 1980) with 25, 50, 75, and $100 \%$ of the concentrations of salts, with 0 or $2 \mathrm{~g} \mathrm{~L}^{-1}$ of activated charcoal (Dinâmica ${ }^{\circledR}$ ), $30 \mathrm{~g} \mathrm{~L}^{-1}$ of sucrose, $\mathrm{pH}$ adjusted in 5.7, solidified with $4 \mathrm{~g} \mathrm{~L}^{-1}$ of agar-agar (Dinâmica ${ }^{\circledR}$ ) and autoclaved at $121^{\circ} \mathrm{C}\left(1 \mathrm{~kg} \mathrm{~m}^{-2}\right)$ for $20 \mathrm{~min}$.

After the inoculation, the culture was conducted in a photoperiod of 16 hours, temperature of $25 \pm 3^{\circ} \mathrm{C}$, relative humidity of $45 \pm 0.5 \%$, and photon flux density of

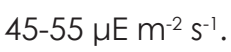

The experiment was performed in a completely randomized design with 20 replications per treatment, with each experimental plot represented by a test tube containing one nodal segment, in a $2 \times 4 \times 2$ factorial scheme (culture medium $x$ concentration of salts $x$ activated charcoal).

The following variables were evaluated at 30 days after inoculation: Formation of friable calluses (\%) = callus formation at the base of the nodal segment; Sprouts $(\%)=$ nodal segments with sprout lengths above $0.50 \mathrm{~cm}$; Index of formation of friable calluses: $0=$ without formation of calluses, $1(1 / 4), 2(2 / 4), 3$ (3/4), and 4 (4/4) of the base of the segments with friable calluses; and sprout length $(\mathrm{cm})$. At 30 days after subcultivation, the following variables were evaluated: sprouts (\%); and sprout length $(\mathrm{cm})$.

The data were subjected to analysis of variance and the means were subjected to the Scott-Knott test at $5 \%$ probability using the SAS statistical software (Statistical Analysis Software).

\section{In vitro germination of zygotic embryos}

The tamarind seeds were imbibed in deionized water for 48 hours to facilitate the removal of the zygotic embryos with the aid of a surgical scalpel. The explants were immersed in $70 \%$ ethanol ( $v: v)$ for one minute and later for 30 minutes in $1 \%$ active chlorine (Qboa ${ }^{\circledR}$ ) with three drops of a neutral detergent (Tween 20) (Dinâmica ${ }^{\circledR}$ ).

After the disinfestation, a triple wash was performed in a horizontal laminar flow cabinet using distilled and autoclaved water. Afterward, the vegetal material was horizontally inoculated in test tubes $(20 \times 150$ $\mathrm{mm}$ ) filled with $20 \mathrm{~mL}$ of the culture media, and sealed with transparent plastic wrap.

The treatments consisted of the use of the MS (Murashige \& Skoog, 1962) or WPM media (Lloyd \& Mccown, 1980) with $25,50,75$, and $100 \%$ of the salt concentrations, with 0 or $2 \mathrm{~g} \mathrm{~L}^{-1}$ of activated charcoal (Dinâmica ${ }^{\circledR}$ ), and $30 \mathrm{~g} \mathrm{~L}^{-1}$ of sucrose, $\mathrm{pH}$ adjusted in 5.7, solidified with $4 \mathrm{~g} \mathrm{~L}^{-1}$ of agar-agar (Dinâmica ${ }^{\circledR}$ ), and autoclaved at $121^{\circ} \mathrm{C}\left(1 \mathrm{~kg} \mathrm{~m}^{-2}\right)$ for 20 minutes.

After the inoculation, the material was maintained in a photoperiod of 16 hours at a temperature of $25 \pm 3$ ${ }^{\circ} \mathrm{C}$, relative humidity of $45 \pm 0.5 \%$, and photon flux density of $45-55 \mu \mathrm{E} \mathrm{m} \mathrm{m}^{-2} \mathrm{~s}^{-1}$.

The experiment was performed in a completely randomized design, with 20 replications per treatment, with each experimental plot represented by a test tube 
containing one zygotic embryo, in a $2 \times 4 \times 2$ factorial scheme (culture medium $x$ salt concentrations $x$ activated charcoal).

The following variables were evaluated at 30 days after inoculation: germinated zygotic embryos (\%) = zygotic embryos with developed plumule and radicle; and plantlet length $(\mathrm{mm})$. The length of the plantlets $(\mathrm{mm})$ was evaluated 30 days after subcultivation.

The data were subjected to analysis of variance, and the means were subjected to the Scott-Knott test at $5 \%$ probability, using the SAS statistical software (Statistical Analysis Software).

\section{Results and Discussion}

In vitro establishment of tamarind nodal segments The MS + CA medium in the salt concentration of $25 \%$ (Figure $1 \mathrm{~A}$ ), even with the formation of calluses (78.95\%) at the base of the explants, presented the highest mean of nodal segments with sprouts $(57.90 \%$ ) (Figure 1B). The formation of calluses is not interesting since the purpose of the germplasm bank is to conserve the genetic characteristics of each species and, from this perspective, the indirect pattern of organogenesis is not viable since the somaclonal variation occurs mainly from the propagation through calluses. It is noted that the callus formation index presented a significant difference by the $\mathrm{F}$ test both in the isolate factors and in the triple interaction (Table 1).

The WPM culture medium presented the highest callus formation index (1.39) and the highest sprout length (0.39 cm), differing from the MS medium (Table 1).
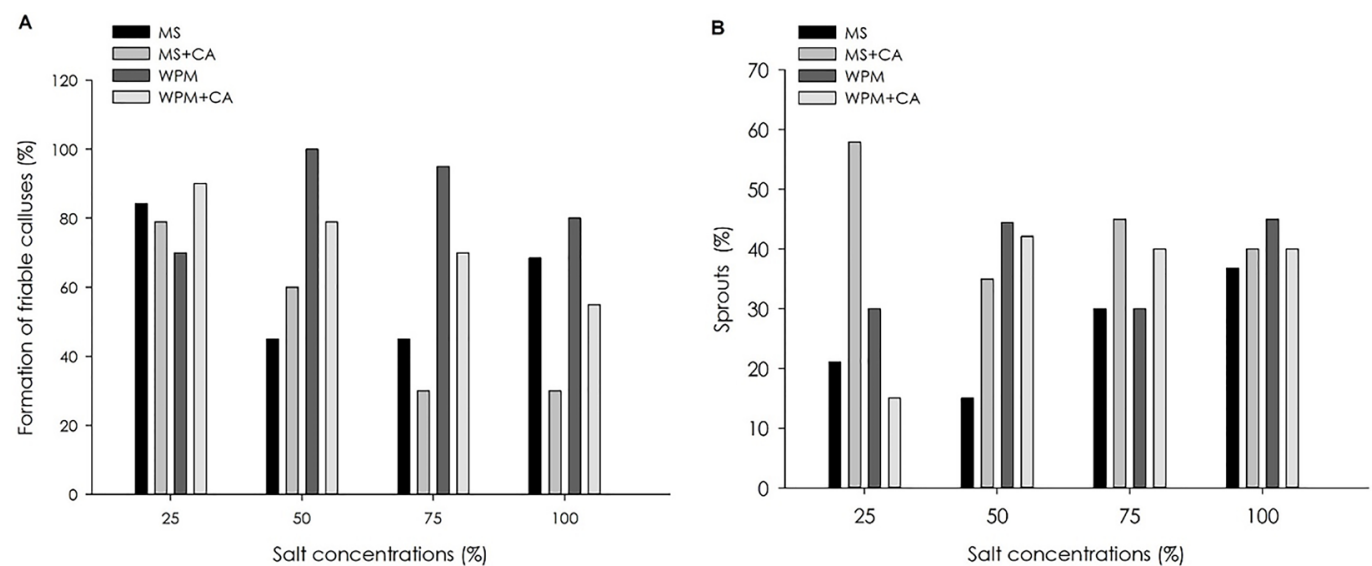

Figure 1. Formation of friable calluses (\%) and sprouts (\%) in nodal segments of Tamarindus indica L. in the culture medium and salt concentrations at 30 days after inoculation.

Table 1. Analysis of variance for the formation rate of friable calluses and sprout length of in vitro nodal segments of tamarind (Tamarindus indica L.) in culture media, salt concentrations, and activated charcoal at 30 days after inoculation

\begin{tabular}{|c|c|c|}
\hline \multirow{2}{*}{ Variation Source } & Formation of Friable Calluses & Sprout Length $(\mathrm{cm})$ \\
\hline & \multicolumn{2}{|c|}{ Mean Square } \\
\hline Media (M) & $62.4204^{* *}$ & $1.6847^{* n}$ \\
\hline Salt concentrations (SC) & $0.7500^{\mathrm{NS}}$ & $0.5422^{\mathrm{NS}}$ \\
\hline Activated charcoal (AC) & $282.6092^{* *}$ & $0.0043^{\mathrm{NS}}$ \\
\hline $\mathrm{M} \times \mathrm{SC}$ & $2.4119^{\text {NS }}$ & $0.4108^{\mathrm{NS}}$ \\
\hline$M \times A C$ & $63.2206^{* *}$ & $0.6112^{\mathrm{NS}}$ \\
\hline$S C \times A C$ & $0.9783^{\mathrm{NS}}$ & $0.0848^{\mathrm{NS}}$ \\
\hline$M \times S C \times A C$ & $2.7245^{*}$ & $0.1279^{N S}$ \\
\hline CV (\%) & 68.63 & 74.59 \\
\hline Media & \multicolumn{2}{|c|}{ General Means } \\
\hline MS & $0.50 \mathrm{~B}^{1}$ & $0.25 \mathrm{~B}^{1}$ \\
\hline WPM & $1.39 \mathrm{~A}$ & $0.39 \mathrm{~A}$ \\
\hline \multicolumn{3}{|l|}{ Salt concentrations (\%) } \\
\hline 25 & 0.83 & 0.24 \\
\hline 50 & 1.03 & 0.26 \\
\hline 75 & 0.89 & 0.40 \\
\hline 100 & 1.03 & 0.38 \\
\hline \multicolumn{3}{|l|}{ Activated charcoal $\left(\mathrm{g} \mathrm{L}^{-1}\right)$} \\
\hline 0 & $1.90 \mathrm{~A}^{1}$ & 0.32 \\
\hline 2 & $0.00 \mathrm{~B}$ & 0.32 \\
\hline General Mean & 0.95 & 0.32 \\
\hline
\end{tabular}


It is observed that the highest callus formation index at the base of the nodal segments was observed in the WPM medium without activated charcoal (2.80), differing from the MS medium (1.00) (Table 2). However, the addition of $2 \mathrm{~g} \mathrm{~L}^{-1}$ of activated charcoal, both in the MS and in the WPM media, inhibited the formation of calluses. According to Glocke et al. (2006), the WPM medium is the most adequate for the formation of calluses and, therefore, it serves as an inducer for direct embryogenesis, such as reported in this experiment.

Table 2. Formation rate of friable calluses in in vitro nodal segments of tamarind (Tamarindus indica L.) in culture media and activated charcoals at 30 days after inoculation.

\begin{tabular}{ccc}
\hline Activated charcoal $\left(\mathbf{g ~ L}^{-1}\right)$ & Formation of Friable Calluses & WPM \\
\hline & MS & $2.80 \mathrm{Aa}$ \\
2 & $1.00 \mathrm{Ab}$ & $0.00 \mathrm{Ba}$ \\
\hline General Mean & $0.00 \mathrm{Ba}$ & 1.40 \\
\hline *Different uppercase letters in the rows and lowercase in the columns differ by the Scott-Knott test at 5\% probability.
\end{tabular}

When statistically comparing the interaction between the three evaluated factors, only the WPM medium without activated charcoal presented higher means for the callus formation index, differing from the treatment that used WPM and the addition of $2 \mathrm{~g} \mathrm{~L}^{-1}$ of activated charcoal and from the MS medium without charcoal (Table 3). The 25\% salt concentration in the WPM medium without charcoal differed from the remaining treatments, presenting the lowest formation rate of friable calluses (2.05).

Table 3. Formation of friable calluses in in vitro nodal segments of tamarind (Tamarindus indica L.) in culture media, salt concentrations, and activated charcoal at 30 days after inoculation.

\begin{tabular}{|c|c|c|c|c|}
\hline \multirow{4}{*}{ Salt concentrations (\%) } & \multicolumn{4}{|c|}{ Formation of Friable Calluses } \\
\hline & \multicolumn{2}{|c|}{ MS } & \multicolumn{2}{|c|}{ WPM } \\
\hline & \multicolumn{4}{|c|}{ Activated charcoal $\left(\mathrm{g} \mathrm{L}^{-1}\right)$} \\
\hline & 0 & 2 & 0 & 2 \\
\hline 25 & $1.26 \mathrm{Aa}^{*}(\mathrm{~b})^{1}$ & $0.00 \mathrm{Ab}(\mathrm{a})$ & $2.05 \mathrm{Ba}(\mathrm{a})$ & $0.00 \mathrm{Ab}(\mathrm{a})$ \\
\hline 50 & $0.95 \mathrm{Aa}(\mathrm{b})$ & $0.00 \mathrm{Ab}(\mathrm{a})$ & $3.33 \mathrm{Aa}(\mathrm{a})$ & $0.00 \mathrm{Ab}(\mathrm{a})$ \\
\hline 75 & $0.70 \mathrm{Aa}(\mathrm{b})$ & $0.00 \mathrm{Ab}(\mathrm{a})$ & $2.85 \mathrm{Aa} \mathrm{(a)}$ & $0.00 \mathrm{Ab}(\mathrm{a})$ \\
\hline 100 & $1.11 \mathrm{Aa}(\mathrm{b})$ & $0.00 \mathrm{Ab}(\mathrm{a})$ & $3.00 \mathrm{Aa}(\mathrm{a})$ & $0.00 \mathrm{Ab}(\mathrm{a})$ \\
\hline General Mean & 1.01 & 0.00 & 2.81 & 0.00 \\
\hline
\end{tabular}

The presence of activated charcoal inhibited the formation of calluses in the explants, in all treatments, differing from those without this additive (Table 3). According to Villa et al. (2014), this addition modifies the composition of the culture medium, adsorbs inhibitory substances produced by the medium itself and toxic substances (phenols and/or quinones) produced during the autoclaving process, or released by the explants, whose tissues underwent lesions, thus inhibiting the formation of calluses. Therefore, if indirect embryogenesis is the intention, the WPM medium is the most suitable for callogenesis in tamarind nodal segments without the use of activated charcoal.

At 30 days after subcultivation, the WPM medium with $100 \%$ of the salts provided $75 \%$ of the nodal segments with sprouts (Figure 2). According to Lencina et al. (2014), this medium was specially developed for woody species and presents a $25 \%$ concentration of nitrate ions, with higher amount of thiamine and ammonium, which may stimulate the growth of the explants due to the low content of nitrogen in the ammoniacal form when compared to the MS medium, a fact that was evidenced in this experiment. Furthermore, the reduced supply of $\mathrm{N}$ in the in vitro culture media is important for direct formation, favoring the development of lateral buds.

Regarding the sprout length, only for the triple interaction of the evaluated factors there was no significant difference by the Ftest (Table 4). The MS medium provided sprouts with $0.35 \mathrm{~cm}$ length, which is above the treatments with the WPM medium. The salt concentration of $75 \%$ and the presence of $2 \mathrm{~g} \mathrm{~L}^{-1}$ of activated charcoal in the evaluated treatments also favored the growth in length of the sprouts when statistically compared in an isolated manner (Table 4).

After the subcultivation, it was observed that the MS medium with $75 \%$ of salts provided the highest sprout length mean $(0.63 \mathrm{~cm})$, differing from the remaining concentrations in the medium and when compared to the WPM medium in the same concentration (Table 5). The MS medium presents higher concentration of nitrate ions, working as a nitrogen source, which is essential for the vegetative growth of the plants, and according to 
Vengadesan et al. (2002), this medium is very used in species of the Fabaceae family, especially in the genus Acacia, since it increases the sprout growth.

The MS and WPM media were not statistically different in the absence of activated charcoal, with 0.37 and $0.29 \mathrm{~cm}$, respectively. The activated charcoal did not influence the sprout growth in the MS medium (Table 5). According to Schwalbert et al. (2015), the addition of activated charcoal to the culture medium has been used for the growth and development of plant cells.

However, there is an effect of the activated charcoal on the sprout growth in several plant species, which was not observed in this experiment since there was no statistical difference in the MS medium, either added or not with this additive (Table 5). However, Quoirin et al. (2001), when adding $2.0 \mathrm{~g} \mathrm{~L}-1^{1}$ of charcoal in $3 / 4$ of the MS medium, observed an increase in the sprout length of Acacia mearnsii (Fabaceae).

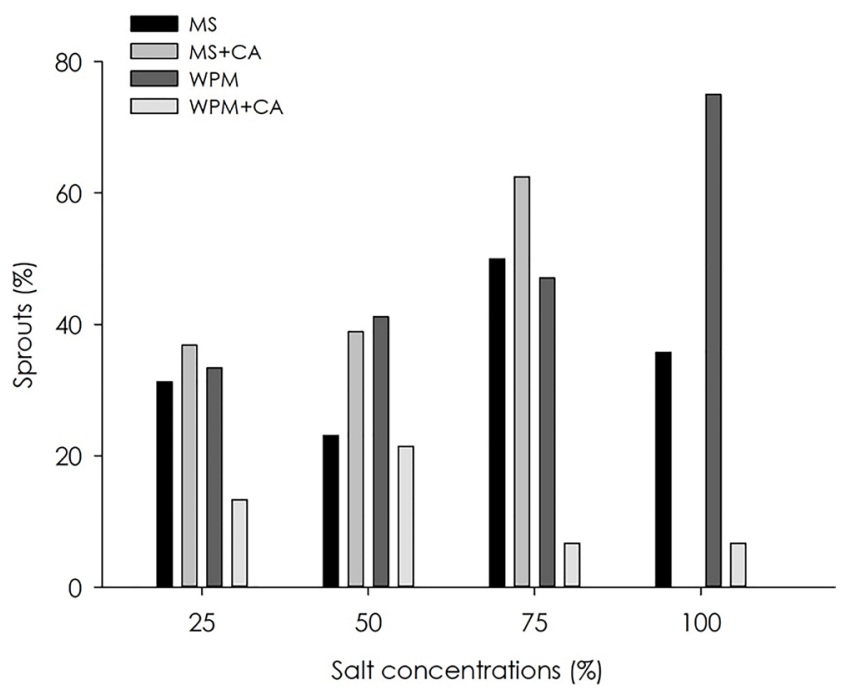

Figure 2. Sprouts (\%) in nodal segments of Tamarindus indica L. in culture media, salt concentrations, and activated charcoal at 30 days after subcultivation.

Table 4. Analysis of variance for the sprout length of in vitro nodal segments of tamarind (Tamarindus indica L.) in culture media, salt concentrations, and activated charcoal at 30 days after subcultivation.

\begin{tabular}{|c|c|}
\hline \multirow{2}{*}{ Variation Source } & Sprout Length $(\mathrm{cm})$ \\
\hline & Mean Square \\
\hline Media (M) & $1.4237^{* *}$ \\
\hline Salt concentrations (SC) & $0.4172^{*}$ \\
\hline Activated charcoal (AC) & $0.7369^{*}$ \\
\hline $\mathrm{M} \times \mathrm{SC}$ & $0.7201^{* *}$ \\
\hline$M \times A C$ & $0.7060^{*}$ \\
\hline$S C \times A C$ & $0.4802^{*}$ \\
\hline$M \times S C \times A C$ & $0.0242^{\mathrm{NS}}$ \\
\hline CV (\%) & 50.21 \\
\hline Media & General means \\
\hline MS & $0.35 \mathrm{~A}^{1}$ \\
\hline WPM & $0.20 \mathrm{~B}$ \\
\hline \multicolumn{2}{|l|}{ Salt concentrations (\%) } \\
\hline 25 & $0.24 \mathrm{~B}^{1}$ \\
\hline 50 & $0.26 \mathrm{~B}$ \\
\hline 75 & $0.39 \mathrm{~A}$ \\
\hline 100 & $0.20 \mathrm{~B}$ \\
\hline \multicolumn{2}{|l|}{ Activated charcoal $\left(\mathrm{g} \mathrm{L}^{-1}\right)$} \\
\hline 0 & $0.33 \mathrm{~A}^{1}$ \\
\hline 2 & $0.22 \mathrm{~B}$ \\
\hline
\end{tabular}


Table 5. Sprout length in in vitro nodal segments of tamarind (Tamarindus indica L.) in culture media and salt concentrations at 30 days after subcultivation.

\begin{tabular}{ccc}
\hline \multirow{2}{*}{ Salt concentrations (\%) } & \multicolumn{2}{c}{ Sprout Lengths (cm) } \\
\cline { 2 - 3 } & MS & WPM \\
\hline 25 & $0.33 \mathrm{Ba}^{* *}$ & $0.15 \mathrm{Aa}$ \\
\hline 50 & $0.29 \mathrm{Ba}$ & $0.22 \mathrm{Aa}$ \\
\hline 75 & $0.63 \mathrm{Aa}$ & $0.19 \mathrm{Ab}$ \\
\hline 100 & $0.17 \mathrm{Ba}$ & $0.24 \mathrm{Aa}$ \\
\hline Activated charcoal $\left(\mathbf{g ~ L}^{-1}\right)$ & $\mathbf{M S}$ & $\mathbf{W P M}$ \\
\hline 0 & $0.37 \mathrm{Aa}$ & $0.29 \mathrm{Aa}$ \\
\hline 2 & $0.33 \mathrm{Aa}$ & $0.08 \mathrm{Bb}$ \\
\hline ** Different uppercase letters in the rows and lowercase in the columns are statistically different by the Scott-Knott test at 5\% probability.
\end{tabular}

Kowalski and Staden (2001) reported that the use of $2.0 \mathrm{~g} \mathrm{~L}^{-1}$ of activated charcoal in the WPM culture medium suits the sprout growth in Podocarpus henkelii, which is not related in this research with the in vitro cultivation of tamarind, in which this medium, with the presence of the additive, reduced the sprout length (Table 5).

In a literature review, Vengadesan et al. (2002) mentioned that in Acacia koa and Acacia mangium the medium with high salt concentrations favored the sprout growth in the nodal segments, allowing the micropropagation of these species. The authors also detailed that the addition of activated charcoal and changes in the salt concentration of the culture medium are effective for the good in vitro establishment of several species of the Fabaceae family. Thus, it is inferred that the

A

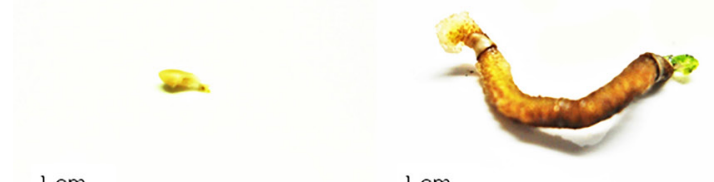

species behave differently, which makes research in this area of great importance for the optimization of the in vitro culture protocol.

In vitro germination of zygotic embryos of tamarind

In the present experiment, it is verified that the zygotic embryo of tamarind is axial, with a straight shape, light yellow color, and invaginated (Figure 3A), with the embryo presenting a curvature during the in vitro germination (Figure 3B). Its growth is slow and the hypocotyl-root axis is arciform, with plumules containing bifoliolate rudiments (Figure $3 \mathrm{C}$ ) and a perceptible radicle (Figure 3D), such as observed by Sousa et al. (2010). The plumule has a pair of light green leaves, and the radicle is lignified, with color from light yellow to light brown and a whitish root cap (Figures $3 C$ and 3D).
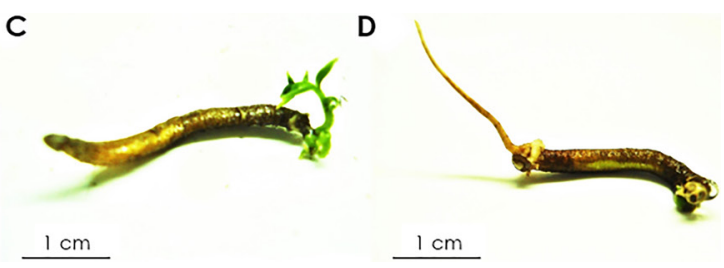

$\underline{\mathrm{cm}}$

Figure 3. Zygotic embryo of tamarind (Tamarindus indica L.) (A); in the germination stage, (B) with development of the plumule (C) and radicle (D). Source: Antonio Flávio Arruda Ferreira.

The highest percentages of germinated embryos (55 and 60\%) were observed in the WPM medium with the addition of $2 \mathrm{~g} \mathrm{~L}^{-1}$ of activated charcoal, with 25 and $50 \%$ of salt concentration, respectively (Figure 4). Bonetti et al. (2016) also did not observe any significant differences when working with different culture media in the germination of zygotic embryos of cultivars of African oil palm (Elaeis guinnensis x Elaeis oleifera). Generally, the median germination of the embryos and the low percentage of development of the shoot and root parts may be related to the embryonic viability of the tamarind (Figure 4), which, according to Bonetti et al. (2016), are extremely interlinked factors.

Borcioni and Negrelle (2012) did not observe satisfactory germination of the zygotic grugru palm [Acrocomia aculeata (Jaca.) Lodd. Ex Martius] when using a culture medium exempt of nutrients or with reduced salt concentrations. The authors also affirmed that for the germination of this type of explant there is a need for high nutrient concentrations, which did not occur in the tamarind embryos, presenting a general mean of approximately $43 \%$ of germination (Figure 4).

García et al. (2002) reported that embryos of several species use their own reserves to promote the in vitro germination, which was not observed in the tamarind of the present study. According to Weidlich et al. (2010), in the Fabaceae family, the nutrient reserve is accumulated in the cotyledons, working as an energetic 
supplementation for the cell metabolism in the initial moments of germination. This information contributes for the results obtained in this experiment, since the zygotic embryos were inoculated without the cotyledons and did present a high germination percentage when compared to the germination rate of the seeds of this species, which may reach $92.7 \%$ (Ferreira et al., 2018), suggesting that the tamarind embryos are not autotrophic.

The growth in length of the embryos at 30 days after inoculation presented a significant difference by the $\mathrm{F}$ test in the interaction between the culture media used and the addition of activated charcoal (Table 6).

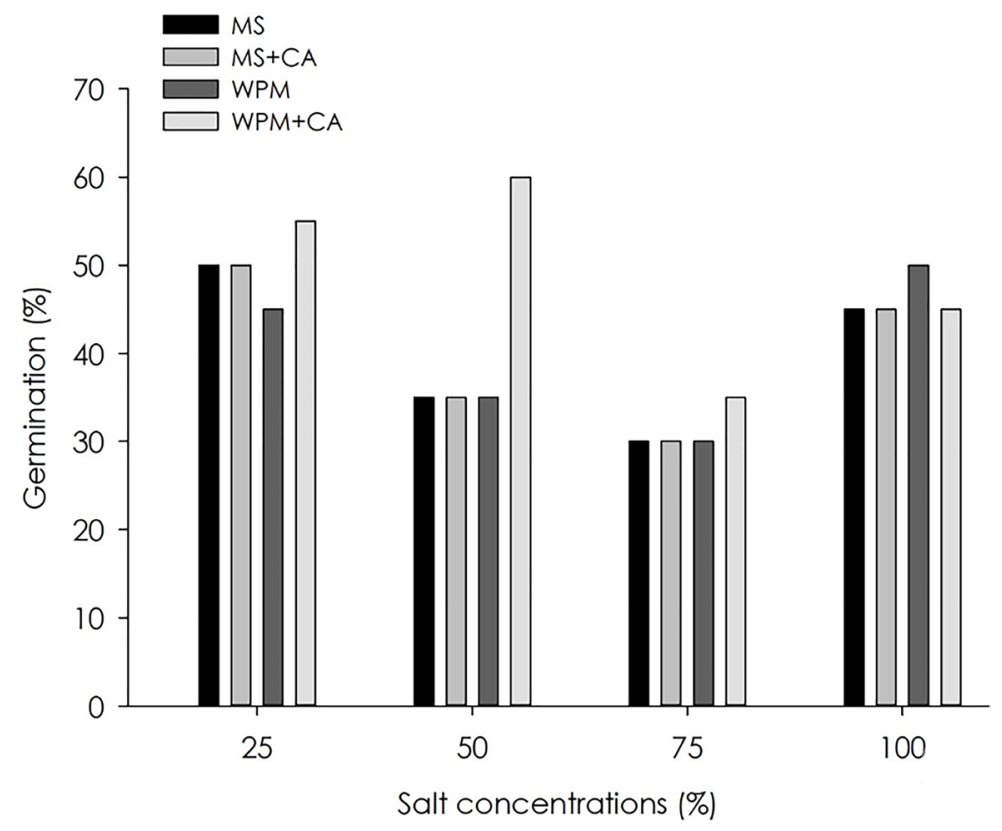

Figure 4. Germination (\%) of zygotic embryos of tamarind (Tamarindus indica L.) in culture media, salt concentrations, and activated charcoal at 30 days after inoculation.

Table 6. Analysis of variance for the length of the plantlets originated from in vitro zygotic embryos of tamarind (Tamarindus indica L.) in culture media, salt concentrations, and activated charcoal at 30 days after inoculation.

\begin{tabular}{|c|c|}
\hline \multirow{2}{*}{ Variation Source } & Length (cm) \\
\hline & Mean Square \\
\hline Media (M) & $0.0769 \mathrm{NS}$ \\
\hline Salt Concentrations (SC) & $1.6457^{\mathrm{NS}}$ \\
\hline Activated charcoal (AC) & $4.1488^{\mathrm{NS}}$ \\
\hline$M \times S C$ & $1.6483^{\mathrm{NS}}$ \\
\hline$M \times A C$ & $9.0524^{*}$ \\
\hline$S C \times A C$ & $0.0775^{\mathrm{NS}}$ \\
\hline$M \times S C \times A C$ & $1.2297^{\mathrm{NS}}$ \\
\hline CV (\%) & 58.14 \\
\hline Media & General means \\
\hline MS & 1.96 \\
\hline WPM & 1.92 \\
\hline \multicolumn{2}{|l|}{ Salt concentrations (\%) } \\
\hline 25 & 1.87 \\
\hline 50 & 1.76 \\
\hline 75 & 2.28 \\
\hline 100 & 1.90 \\
\hline \multicolumn{2}{|l|}{ Activated charcoal $\left(\mathrm{g} \mathrm{L}^{-1}\right)$} \\
\hline 0 & 1.74 \\
\hline 2 & 2.09 \\
\hline
\end{tabular}

According to Mikovski et al. (2015), the activated charcoal adsorbs inhibitory substances, such as phenolic compounds, abscisic acid (ABA), and ethylene exsudated by the zygotic embryo throughout the in vitro cultivation, which occurred in this study. Accordingly, the supplementation of activated charcoal in the culture medium adsorbed and sequestered toxins produced in the in vitro environment, damaging the germination of the embryo and its later conversion into plantlets (Nunes et al., 2008; Pan \& Staden, 1998). 
In the interaction between the media and the use of activated charcoal, the length of the tamarind embryos was higher in the WPM medium, with $2 \mathrm{~g} \mathrm{~L}^{-1}$ (Table 7). For Mikovski et al. (2015), the activated charcoal positively influences the in vitro growth of the plantlets. The beneficial effect on the in vitro response when using the activated charcoal occurs due to the adsorption of plant growth regulators and other organic compounds (Cheruvathur et al., 2010).

At 30 days after subcultivation, only the salt concentration presented a significant difference by the $F$ test for the length of the plantlets originated from the zygotic embryos of tamarind (Table 8). The salts at 50, 75, and $100 \%$ increased the growth of the formed plantlets, statistically differing from the treatments with $25 \%$ of salts.

The higher salt concentrations in the evaluated treatments were responsible for the increase in the length of the in vitro plantlets, and could be adjusted in a quadratic regression (Figure 5). Martendal et al. (2013) reported that the variation in the salt concentration does not have any significant influence on the germination percentage and on the length of embryos of murici (Byrsonima cydoniifolia A. Juss.), which was not observed in this study since concentrations above $50 \%$ favor the length of tamarind plantlets formed from zygotic embryos.

Considering the physiological specificities of each species, the choice of better environmental conditions and the adequate culture medium for the in vitro germination of zygotic embryos are of extreme importance for studies on plant tissue culture (Moreira et al., 2012). Furthermore, these characteristics, along with endogenous factors, are essential for the success of the propagation method.

Table 7. Length of plantlets originated from in vitro zygotic embryos of tamarind (Tamarindus indica L.) in culture media and activated charcoal at 30 days after inoculation.

\begin{tabular}{ccc}
\hline Activated charcoal $\left(\mathbf{g ~ L}^{-1}\right)$ & Length $\mathbf{( c m})$ \\
\hline 0 & $\mathbf{M S}$ & WPM \\
\hline 2 & $2,04 \mathrm{Aa}^{* *}$ & $1,40 \mathrm{Bb}$ \\
General mean & $1.91 \mathrm{Aa}$ & $2.29 \mathrm{Aa}$ \\
\hline **Different uppercase letters in the rows and lowercase in the columns are statistically different by the Scott-Knott test at 5\% \\
probability.
\end{tabular}

Table 8. Analysis of variance for the length of the plantlets originated from the in vitro zygotic embryos of tamarind (Tamarindus indica L.) in culture media, salt concentrations, and activated charcoal at 30 days after subcultivation.

\begin{tabular}{|c|c|}
\hline \multirow{2}{*}{ Variation Source } & Length $(\mathrm{cm})$ \\
\hline & Mean Square \\
\hline Media (M) & $2.4057^{\mathrm{NS}}$ \\
\hline Salt concentrations (SC) & $3.8656^{*}$ \\
\hline Activated charcoal (AC) & $0.2834^{\mathrm{NS}}$ \\
\hline$M \times S C$ & $0.9163^{\mathrm{NS}}$ \\
\hline$M \times A C$ & $2.5574^{\mathrm{NS}}$ \\
\hline$S C \times A C$ & $2.5832^{\mathrm{NS}}$ \\
\hline$M \times S C \times A C$ & $0.8639^{N S}$ \\
\hline CV (\%) & 42.59 \\
\hline Media & General Means \\
\hline MS & 2.67 \\
\hline WPM & 2.37 \\
\hline \multicolumn{2}{|l|}{ Salt concentrations (\%) } \\
\hline 25 & $2.09 B^{1}$ \\
\hline 50 & $2.55 \mathrm{~A}$ \\
\hline 75 & $2.94 \mathrm{~A}$ \\
\hline 100 & $2.77 \mathrm{~A}$ \\
\hline \multicolumn{2}{|l|}{ Activated charcoal $\left(\mathrm{g} \mathrm{L}^{-1}\right)$} \\
\hline 0 & 2.58 \\
\hline 2 & 2.48 \\
\hline
\end{tabular}




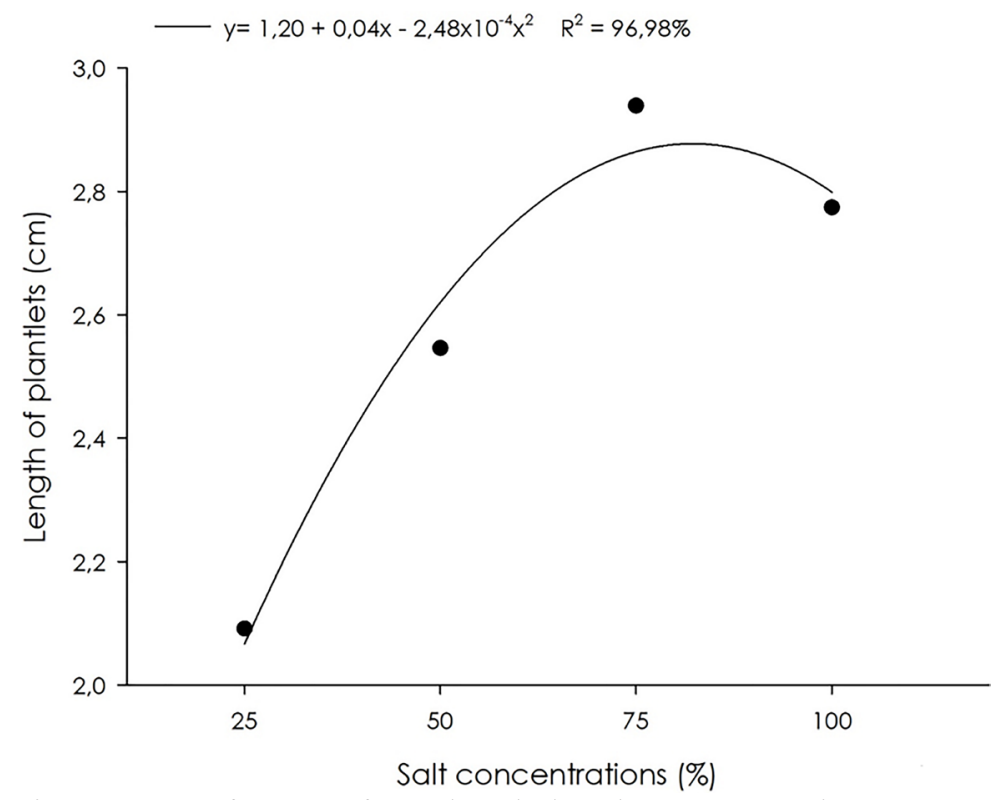

Figure 5. Length of plantlets of Tamarindus indica L. in salt concentrations at 30 days after subcultivation.

\section{Conclusions}

In the conditions in which the experiments were performed, it can be concluded that the in vitro establishment of tamarind nodal segments is viable in the MS medium with $75 \%$ of salts, added by $2 \mathrm{~g} \mathrm{~L}^{-1}$ of activated charcoal. It is also concluded that for the germination of zygotic embryos, there is no influence of the treatments. However, to increase the length of the formed plantlets, it is necessary to use the MS and WPM media with com $75 \%$ of salts.

\section{Acknowledgments}

The authors thank the FAPESP for the financial assistance (Process: 12/12287-0); to Dr. Fabiano Guimarães Silva and to the Federal Institute of Education, Science, and Technology of Goiano - Campus Rio Verde for the availability of the laboratory for the conduction of the experiments, and to the LEA (Laboratory of Applied Statistics), funded by FAPESP (Process: 2015/18225-4), responsible for the statistical analysis of the experiments.

\section{References}

Bonetti, K.A.P., Quoirin, M., Quisen, R.C., Lima, S.C.S. 2016. In vitro germination of zygotic embryos of hybrid BRS Manicoré (E. guineensis X E. oleifera). Anais da Academia Brasileira de Ciências 88: 1841-1850.

Borcioni, E., Negrelle, R.R.B. 2012. Aplicação de análogo de brassinosteroide (Biobras $16^{\circledR}$ ) sobre a germinação e crescimento in vitro de embriões zigóticos e aclimatização de plântulas de bocaiuva. Ciência Rural 42: 270-275.

Brandstetter, D.R., Nadal, M.C., Camargo, S.S., Assis, A.M. de, Schuch, M.W., Peil, R.M.N., Faria, R.T. 2016. Growth regulators and substrates for Oncidium baveri Lindl. micropropagation. Semina: Ciências Agrárias 37: 29012910.

Campos, V.C.A., Lima-Brito, A., Gutierrez, I.E.M. de, Santana, J.R.F., Souza, A.V.V. 2013. Micropropagação de umburana de cheiro. Ciência Rural 43: 639-644.

Cheruvathur, M.K., Abraham, J., Mani, B., Thomas, T.D. 2010. Adventitious shoot induction from cultured intermodal explants of Malaxis acuminate D. Don, a valuable terrestrial medicinal orchid. Plant Cell, Tissue and Organ Culture 101: 163-170.

Fermino Junior, P.C.P, Scherwinski-Pereira, J.E. 2012. Germinação e propagação in vitro de cerejeira (Amburana acreana (Ducke) A.C. Smith - Fabaceae). Ciência Florestal 22: 1-9.

Ferreira, A.F.A., Monteiro, L.N.M., Rodrigues, G.F.R., Oliveira, N.B., Boliani, A.C. 2018. In vitro cultivation of Tamarindus indica L.: explants obtention and contamination in culture medium. Comunicata Scientiae 9: 298-302.

García, J.L., Troncoso, J., Sarmiento, R., Trancoso, A. 2002. Influence of carbon source and concentration on the in vitro development of olive zygotic embryos and explants raised from them. Plant Cell, Tissue and Organ Culture 69: 95-100.

Glocke, P., Delaporte, K., Collins, G., Sedgley, M. 2006. Micropropagation of juvenile tissue of Eucalyptus erythronema x Eucalyptus stricklandii cv. 'Urrbae Gem'. In vitro Cellular and Developmental Biology Plant 42: 139143.

Gutiérrez, I.E.M., Nepomuceno, C.F., Ledo, C.A.S., Santana, J.R.F. 2011 . Regeneração in vitro via organogênese direta de Bauhinia cheilantha. Revista Ciência Rural 41: 260-265.

Kowalski, B., Staden, J. 2001. Micropropagation of Podocarpus henkelii and P. elongates. South African Journalof Botany 67: 362-366. 
Lemes, C.S.R., Sorgato, J.C., Soares, J.S., Rosa, Y.B.C.J. 2016. Meios de cultivo e sacarose no crescimento inicial in vitro de Miltonia flavescens. Ciência Rural 46: 499-505.

Lencina, K.H., Bisognin, D.A., Kielse, P., Pinmentel, N., Fleig, F.D. 2014. Estabelecimento e crescimento in vitro de plantas de grápia. Ciência Rural 44: 1025-1030.

Lloyd, G., McCown, B. 1980. Commercially feasible micropropagation of montain laurel, Kalmia latifolia, by use of shoot tip culture. Combined Proceedings International Plant Propagators Society 30: 421-327.

Maiti, R., De, D., Ghosh, D. 2018. Antidiabetic effect of $n$-hexane fraction of hydro-methanolic extract of Tamarindos indica Linn. seed in streptozotocin-induced diabetic rat: a correlative approach with in vivo and in vitro antioxidant activities. International Journal Of Pharmaceutical Sciences And Research 9: 1821-1830.

Martendal, C.O., Bernardino, M.M., Pereira, F.D., Silva, F.G., Menezes, C.C.E., Hara, A.C.B.A.M. 2013. In vitro cultivation of zygotic embryos from Murici (Byrsonima cydoniifolia A. Juss.): establishment, disinfection, and germination. Acta Scientiarum. Agronomy 35: 221-229.

Mikovski, A.I., Carvalho, I.F., Sander, N., Silva, C.J., Silva, M.L. 2015. Efeito de sacarose e carvão ativado na germinação e no desenvolvimento in vitro de embriões zigóticos de açaí (Euterpe oleracea). Enciclopédia Biosfera 11:869-877.

Moreira, R.A., Rodrigues, F.A., Monfort, L.E.F., Pires, M., Pasqual, M. 2012. Diferentes meios de cultura no crescimento in vitro de sorvetão. Revista Brasileira de Ciências Agrárias 7: 409-413.

Murashige, T., Skoog, F. 1962. A revised medium for rapid growth and bioassays with tabacco tissue culture. Physiologia Plantarum 15: 473-497.

Nunes, C.F., Pasqual, M., Santos, D.N., Custódio, T.N., Araujo, A.G. 2008. Diferentes suplementos no cultivo in vitro de embriões de pinhão-manso. Pesquisa Agropecuária Brasileira 43: 9-14.

Pan, M.J., Staden, J.V. 1998. The use of charcoal in vitro culture: a review. Plant Growth Regulation 26: 155-163.

Quoirin, M., Silva, M.C., Martins, K.G., Oliveira, D. 2001. Multiplication of juvenile black wattle by microcuttings. Plant Cell, Tissue and Organ Culture 66: 199-205.

Razali, N., Junit, S.M., Ariffin, A., Ramli, N.S.F., Aziz, A.A. 2015. Polyphenols from the extract and fraction of $T$. indica seeds protected HepG2 cells against oxidative stress. BMC Complementary Alternative Medicine 15: $1-16$.

Reis, P.M.C.L., Dariva, C., Vieira, G.A.B., Hense, H. 2016. Extraction and evaluation of antioxidant potential of the extracts obtained from tamarind seeds (Tamarindus indica), sweet variety. Journal of Food Engineering 173: 116-123.

Schwalbert, R., Maldaner, J., Amaral, G.A., Farias, M., Sul, F.R.G. 2015. Multiplicação in vitro de Desmodium incanum em presença de carvão ativado. Enciclopédia Biosfera 21: 1365-1373.

Sousa, D.M.M., Bruno, R.L.A., Dornelas, C.S.M., Alves, E.U., Andrade, A.P., Nascimento, L.C. 2010. Caracterização morfológica de frutos e sementes e desenvolvimento pós-seminal de Tamarindus indica L. - Leguminosae: caesalpinioideae. Revista Árvore 34: 1009-1015.

Vengadesan, G., Ganapathi, A., Amutha, S., Selvaraj, N. 2002. In vitro propagation of Acacia species - a review. Plant Science 163: 663-671.

Villa, F., Pasqual, M., Silva, E.F. 2014. Micropropagação de híbridos de orquídea em meio knudson com adição de vitaminas do meio MS, benzilaminopurina e carvão ativado. Semina: Ciências Agrárias 35: 683-694.

Weidlich, E.W.A., Pescador, R., Uhlmann, A. 2010. Alocação de recursos (carboidratos) no desenvolvimento inicial de plântulas de Schizolobium parahyba (vell.) S.f. Blake (Fabaceae - Caesalpinioideae). Revista Árvore 34: 627-635.

Conflict of Interest Statement: The authors declare that the research was conducted in the absence of any commercial or financial relationships that could be construed as a potential conflict of interest.

All the contents of this journal, except where otherwise noted, is licensed under a Creative Commons Attribution License attribuition-type BY. 